\title{
Natural Law and Contractual Spirit
}

\section{Fang HUANG}

\author{
China University of Mining \& Technology, Beijing, China \\ hf@cumtb.edu.cn
}

Keywords: Natural law, Contractual spirit, Social contract.

\begin{abstract}
The purpose of this paper is that seeking theoretical basis for promotion for legalization of market economy, this paper seeks contemporary value of contractual spirit from the theoretical source of contractual spirit. This paper mainly studies by means of literature reading. The author thinks that, the prerequisite of contractual spirit is equality, knowledge, freedom, and the core of contractual spirit: reciprocity, cooperation, the realization of contractual spirit needs integrity and loyalty. This unscrambles the whole process of contractual spirit from the theoretical source, which is innovative.
\end{abstract}

\section{Introduction}

The contract is the key theme studied in politics philosophy research and the contract spirit has its practical value with the development of market economy in particular. The nature of the market economy is the contract economy and the contractual spirit provide guarantee with operation of the market economy and stable social order.

Mentioned by David Hume in A Treatise of Human Nature, people exist inevitably unilateralism and it still affects social stability after developing into society. Therefore, the remedy is not born in nature but human. Hume has emphasized the effect of human effort in making up for unilateralism and pointed out that effort made by human is the contract. The contract is not necessary the preferred plan people can imagine, but that is our best one in practice. The contract is the result of human civilization development. The scholars in social contract theory has developed and improved the contractual spirit since Hobbes and the social contract gets people from natural condition into civil society. The contractual spirit has already become an important dimension in establishment of social order. The fundamental philosophy of contract, including equality, knowledge, freedom, mutual benefit, cooperation, credibility, philanthropism and tolerance, guides the establishment of human social order. They are the contents which should considered in the process of building social order and conditions in establishing social order. However, this contractual idea derives from natural law and is the key concept expounded from natural law. The proposition of social order of natural law has profound and important influences on establishment of social contractual theory.

\section{Precondition of the Contract: Equality, Knowledge and Freedom}

The contractual spirit not only contains the philosophy of contract in itself, but also includes the precondition before forming contract. Equality is the first condition, which narrated in natural law theory from political philosophers such as Hobbes and Locke. Hobbes considered the reason why the natural condition is the state of war is that people are equal in nature. This equality reflects in natural gift, body power and mind agility. Everyone has enough power to make natural state into war state. One feature is confirmed in the form of law of nature. "Everyone should admit that other people equal with me and it is the pride if we go against this rule.” (Thomas Hobbes, 2012).

He proposed this rule aiming at division of master and servant advocated by Aristotle based on people's intelligence. He thought this is unreasonable and violate the experience. Locke also considered that there have no people enjoy rights exceeding others under the natural condition. People bear natural and equal advantages after they were born without difference and don't exist subordinated and restricted relations. The born equal is the basic proposition in natural law and the 
society is formed to formulate contract under equal natural condition, therefore that is the basic premise of the contract. Certainly, equal contractual spirit is embodied before form of the contract and also reflected in the whole process of the contract. But the later contract formation and performance of the contract will not be present in case of inequality.

The contract resulted from people's rational consideration, people's rational expression shows that he can make the best choice conforming to public interests and long-term development based on current actual condition. Sizing the actual condition is the outcome of performing the right for knowledge. The second precondition of the contract is knowledge. Before reaching an contract, the principal participating in contract has right to know information related to contract formation including what rights give up or obtain, how to perform and compensation for breach of contract and so on. It is impossible to reach an agreement with beast, because they don't understand our language. Alienation of any right cannot be accepted and any right cannot be transferred to others due to incomprehension. There will have no faithful contract result from lacking of mutual acceptance. (Thomas Hobbes, 2012) Knowledge stands for respect to principal of reaching agreement and it is the real willingness when both sides know and understand the contract.

The third precondition of the contract is the freedom. It will be meaningful when the contract is signed under the freedom of parties. The parties of signing the contract make freely choice through their own will on the basis of knowing the facts fully and negotiation clauses can be forward to other parties when necessary until both sides enter into the accepted agreement. This acceptance is the conscious and voluntary behavior, the self awareness, means that free from force of strength, is not the expediency that has to accept because of fear but to accept willingly with your mind and willing to carry out based on contract. This contract made freely is an effective one. "all people-as Locke said - all are equal kings, when some political authority is rooted in, or produce improperly from us - as freedom and equality, rational and logical people-agreed consents, we will shoulder the responsibilities to it”(John Rawls, 2011) Locke believed that the necessary condition of entering into contract is the agreed consents of rational and logical people.

In conclusion, equality is the first precondition, without equality, there will have no the right to knowledge and freedom. Under the condition of inequality, dominant party is easy to cover up unflattering information considering its interests to generate the asymmetrical information between parties of contract. Inequality means that one party can sacrifice freedom of the other party for its freedom. When equality exists, there will have real knowledge and freedom, while knowledge and freedom are the preconditions of ensuring fair, effective and everlasting contract. The knowledge and freedom are embodied in the proactivity and recognition of parties to contract. It will be effective and stable because of active participation to reach an agreement not being accepted by force. Otherwise, the forced party will seek for opportunities to overturn current agreement.

\section{Core of the Contract: Mutual Benefit and Cooperation}

Cooperation and equity are the meaning that should own and core spirit of the contract. Aristotle pointed out in the early time that people are the social animal in nature. Thanks to many inconveniences in natural state, people found that cooperation can make all living and production activities more convenient and effective, therefore, they begin to develop from individual to group lives. These cooperation are free and voluntary behaviors without doubt not the joint conduct in slavery state. People are forced to act together under threat, which means work together not cooperation. People need cooperation in society.

As Rousseau saw it, people are interdependent in social meaning and any people relay on for survival. The dependency relationship is confirmed in the form of contract to confirm and protect this cooperation and ensure everyone's right. The purpose of entering into the contract by parties is for their interests and this purpose of parties' contract is normalized into different demands by various scholars. The purpose of reaching contracts in society developed from people is normalized by Hobbes to seek for peace and protect us. That is his first natural law. "Making people tend to 
passion is desires for fear of death and necessary things for comfortable life, as well as wish obtained everything through our diligence”.(Thomas Hobbes, 2012) Locke believed that this interest is people's rights to life and freedom and property right. Undoubtedly, although total different demands, People give up rights in natural state, aiming at forming the society to enter into contract is to guarantee preferably and achieve rights of their interests and talents. As Hobbes said, "the aim of everyone's voluntary act is to protect some of their benefits." (Thomas Hobbes, 2012) the purpose of reaching contracts determines the nature of the contract. Therefore, people's cooperation in society must be those which can improve and achieve their own interests with mutual benefits.

Hobbes considered that rights are delivered as the joint efforts and things belong to everyone should be distributed equally to them in accordance with natural law. That is the justice of distribution. Everyone should have equivalent performance of contract, any party shall violate the natural law self-protection or seek for peace if fail to perform contracts. "if one people, keeping outwardly humble, performs own all promises with place when other people fail to carry out. Therefore those people just the victim of others, which must be destroyed. All these go against the basis of natural law preserving nature”. On the other hand, if one has enough guarantee, others will obey these natural laws to him, while if he fails, what he seek for is the war not peace. Consequently, the violence destroys his nature. In Hobbes' view, mutual benefit must be an share of mutual advantages and equal performance of contract.

The mutual benefit of Rousseau is discussed on the basis of "self-esteem". Self-love and self-esteem are two things differing human from animals, the former is decided by the nature and the latter generates from the society. The self-esteem generates from comparison of with others whether are accepted and treated equally. Rawls considered "with the improvement of self-esteem, we can accept the rule of mutual benefit and take actions in the light of this rule." This self-esteem is not the unnatural self-esteem suppressing others but equal sense of security obtained through compared with others in group. Namely, their needs and interests are considered with others without discrimination. The mutual benefit is equivalent, therefore, we are willing to be endowed with other people' equal positions when our needs and benefits are treated seriously by others, offering equal considerations for others' benefits and treating others' benefits as the restricted conditions of our behaviors. The mutual benefit depends on justice of people to a large extent and this justice is consistent and common. Parties of the contract can treat interests of public comprehensively and place others into the equivalent positions to consider others' situation and demands.

Mutual benefit is the only form of equity while equity is the surpass and development of mutual benefit. The equity also means the punishment and revivification when the party goes against the contract. While the party is being violated try his best to compensate and restore. The equivalent spirit not only is reflects in the process of obeying the contract, but also relevant punishment for breach of contract. The cooperation of mutual benefit has become the core inspirit of the contract due to dependence of people on society.

\section{Implementation of Contract: Trustworthiness and Fidelity}

Trustworthiness is the key of contract from text to reality, the contract shall be a mere scrap of paper if parties fail to obey without trustworthiness. Hobbes regarded the trustworthiness as a natural law in theory of natural law. The reached contract should be performed, which is the third natural law for Hobbes. He attached great importance to trustworthiness and people who fail to keep faith will be not accepted even being treated as the nature of justice. "Breach for contract means injustice after the faithful contract is reached and definition of the injustice is nonperformance of contract”. (Thomas Hobbes, 2012) He considered that the breach of contract will not obtain reasonable testimony. The idea of gaining eternal blessing for nonperformance of contract is flighty. "There are no any other imaginable ways to save apart from preserving our faithful contract.”(John Rawls, 2011) Hume divides the obligation into natural obligation and 
artificial obligation. The artificial obligations include (1) obligation of justice that means respect of others' properties. (2) Obligation of trustworthiness referring to observance of their promises. (3) loyal civic duties to government."

The effect of faith in the contract is confirmed and valued by social contract theorists. While it is inconsistent with the idea of social contract theorists how to keep faith. There still has difference whether obedience of the contract comes from exterior or human itself.

Hobbes, always denied human nature, believed that human has evil practice such as self-conceit and vanity. The society will fall into the trend of war state under the condition of rare resources. The performance of the contract cannot depend on words, because the power of words is so weak that people cannot perform the contract. Therefore, the people's trustworthiness can be achieved with powerful rights. There has no strong sovereign in the natural state of everyone is equal and everyone will wage a war for their own benefits. The contract is the way to solve this distrust state when people to people are in distrust states. While the contract itself has no guarantee effect, whatmakes a difference is the sovereign forcing to perform this contract with the contract. Therefore, the trustworthiness generates along with conclusion of contracts and powerful joint rights.

Rousseau is full of confidence with human nature and opposed the bad trend of human from Hobbes. He thought that obedience of the contract spirit is more emotions presuming on people's inner heart. Rousseau considered that our culture make this rule is comprehensible and attainable for us and basic system in society can ensure equality between we and others, thus we can accept the rule of mutual benefit and take actions based on this rule with the push of self-esteem. Rousseau paid great attention to inner emotions to contract in observing good faith and this emotion is the acceptance of contract and willing positively to obey and perform the core inspirit embodied in contract. But it doesn't mean that it doesn't need political authority. In his view, the political authority must be considered rationally and accepted psychologically by people.

Therefore, the obedience of contract required for contract inspirit is an essential condition to performance of contract. Otherwise the perfect contract articles just have texts with insignificance.

Trustworthiness is the fidelity and obedience of the contract. So everyone is the behavioral agent of keeping faith. But keeping faith is far from requiring people to be faithful unconditionally to current any articles in keeping faith, even if unreasonable agreements. Observance of good faith is not passive obligations of people but the positive and rational. Meanwhile, observance of good faith requires to be restricted by external system and authority. The behavior of obedience of the contract is affected by external system in two sides, one of which is reflection in respect to everyone. Only respect everyone's interest and emotion, can current or newly formed political authority and its system being recognized and accepted, so that people are willing to be loyal to it. The other effect of the political authority and system is embodied in punishment of violating contract to provide deterrence and restriction. Although contract is accepted by people to reach acceptable level, it cannot guarantee that everyone must obey the contract at any time. Some people will go against the contract for their benefits under unconscionable conditions, requiring restriction of systems. Hence, the requirement of trustworthiness reflected in the contract is aimed at people and systems. The performance depends on both strength of political authority and justice and reason of human.

\section{References}

[1] John Rawls. Lectures on the History of Political Philosophy[M]. TheBelknap Press of Harvard University Press, 2007.

[2] Thomas Hobbes. Leviathan[M]. Hackett Publishing Co, Inc,1994.

[3] Jean-Jacques Rousseau.The Social Contract[M].PENGUIN U.K.,2004.

[4]John Locke. Two Treatises of Government [M].Cambridge University Press, 1988.

[5] David Hume. A Treatise of Human Nature[M].Fontana Press, 1972. 